\title{
The Effectiveness of Counseling through Vasectomy Module in North Kolaka, Indonesia
}

\author{
Askrening, Hendra Yulita \\ Department of Midwifery, Polytechnic of Health Kendari, Indonesia
}

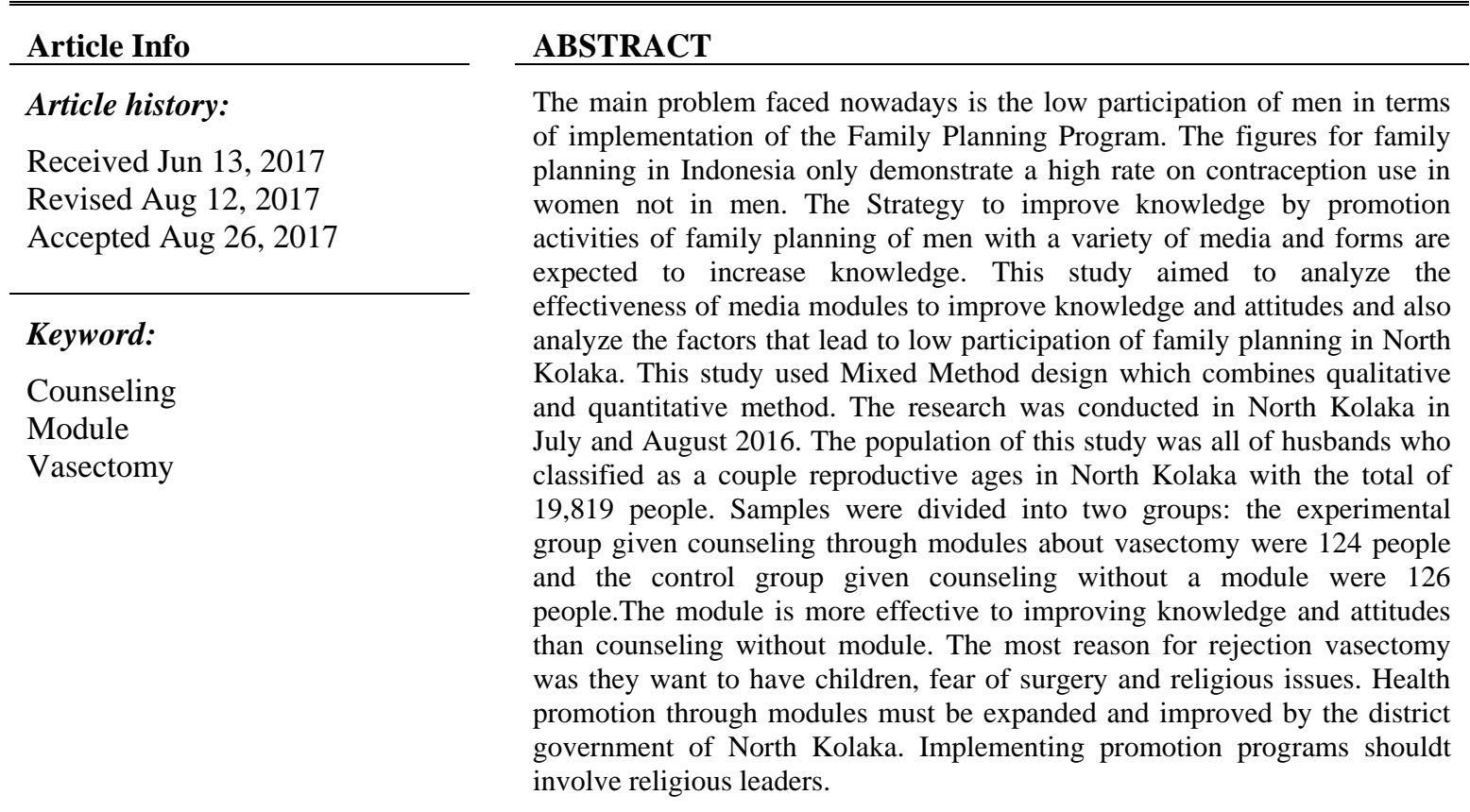

Copyright (C) 2017 Institute of Advanced Engineering and Science. All rights reserved.

\section{Corresponding Author:}

Askrening,

Department of Midwifery,

Polytechnic of Health Kendari, Indonesia.

Email: askreningkdi@gmail.com

\section{INTRODUCTION}

According to the population census of 2010, Indonesia had a population of 237.6 million people, so it is classified as the fourth largest population in the world [1]. It was also reported that the maternal mortality rate in Indonesia reached 228 deaths per 100,000 births. This figure is higher compared to other Asean countries, such as Thailand, Malaysia, Vietnam, Brunei, and Singapore [2]. The Ministry of health of Indonesia in an effort to accelerate the maternal mortality issue policies through the four pillars of safe motherhood, the one is the family planning program. This program is one method to control the population [3].

Reproduction involves both a male and female, but generally, family planning programs just targeting the women [4]-[6]. In developing countries, the service of family planning programs that include targeted information, education and communication in increased knowledge and use of contraception is more focused on women [4],[7]. As a result, the male participation in the implementation of family planning programs to be reduced [8],[9]. The participation of Indonesian married men in family planning programs is still low at 5.5\% [10], if compared with other countries such as Bangladesh 19.1\%, 10.9\% Pakistan, and Nepal $18 \%$, the rate is very low [11]. 
Family planning participant in Indonesia only show a high rate on contraception use in women not in men. The low participation of men in family planning is caused by a variety of demographic factors (age, number of children, and sex of the child), factor of social structure (education, science, religion, socioeconomic status and welfare), factors spouse (wife's health and support a wife ) and the availability of health resources (health insurance, access to information, distance to health facilities and health workers [12].

The major contraception methods at present is vasectomy, and accepted by more than 40 million men as a method of male sterilization in worldwide [13]-[17]. In Indonesia, Generally husband's participation in family planning programs is still low. this is indicated by the opinion of the husband that family planning is a matter for the woman and the woman should sterilized. On the other hand, the low participation of men in to family planning also caused by wives who are less supportive male contraceptive methods, especially on vasectomies. This is due to the fear that the contraceptive vasectomy may be negative consequences that their husbands are cheating and afraid when activities during intercourse is less satisfying [12].

The participation rate of husbands in family planning by using operating method man (vasectomy) in various district in Southeast Sulawesi is still very low. Based on National Family Planning Board (NFPB) Southeast Sulawesi province in 2016, North Kolaka is an area with the lowest attainment of vasectomy than other district in southeast Sulawesi province [18]. Efforts should be made to increase male participation in family planning can be done through the promotion of family planning and the man with the form [19],[20]. This study was aimed to analize the effectiveness of counseling by vasectomy module in North Kolaka district, Southeast Sulawesi Province.

\section{RESEARCH METHOD}

This study used mixed method design which combines qualitative and quantitative method. qualitative methods depth interviews to evaluate local government policy related to the exercise of male contraceptive methods of operation. While the quantitative method is done by using quasi-experimental research design in the form Nonequivalent Control Group Design [21].

The research was conducted in North Kolaka from September to November 2016. The population was the husband who classified as couple reproductive age in North Kolaka as many as 19, 819 people. Sampling using quality assurance LOT (Lot Quality Assurance-LQAS). The purpose is to ascertain whether the population achieve some standards to follow the health care program, in this case the method of family planning services was operation man method or vasectomy.

Based on a sample size table for sampling in the Lot Quality Assurance (LQAS), if no case is acceptable (if no participant of husband receive vasectomy) with $95 \%$ confidence in prevalence to $1.25 \%$ to 20,000 and population husband as couple reproductive age, then obtained a sample size of 238 husband as couple reproductive age [22]. These samples were divided into 2 groups: the experimental group were given counseling through modules vasectomy with the total of 119 people and a control group that were counseling without module with the total of 119 people. This research is a survey by means of sampling using cluster random sampling is random sampling of a group of individuals based on geographic areas, where the sampling plan using a framework that consists of a cluster of clusters [22].

The research intervention is counseling services through vasectomy module, where the final stage of this study is to measure attitudes change. The indicator of attitudes change is acceptance of vasectomy by husband who classified couple reproductive age. This study involve two groups: the experimental group was given counseling and a control group was not given counseling. Both experimental group and control group will be measured before and after intervention (pretest and posttest).

Analysis univariable is used to describe all the variables (knowledge, education and attitude) in the frequency distribution table. Bivariable analysis is used to know the effectiveness of interventions using counseling through vasectomy module towards enhancement of male participation in family planning. Data analysis techniques in this study using the statistical test Paired T.Test. This test is used to compare two sets of data, both experimental group and control group by measurement scale interval and ratio.

\section{RESULTS AND ANALYSIS \\ 3.1. Results}

\subsubsection{Characteristics of respondents based education and occupation}

Table 1 shows characteritics of respondents based educational level. It is indicated the mayority proportion of respondent for education level is Senior high school with the total of $46.4 \%$. 
Table 1. The characteristics of Respondents Based on Education Education Level

\begin{tabular}{lcccccc}
\hline \multirow{2}{*}{ Education Level } & \multicolumn{2}{c}{ Counseling without Module } & Counseling by Module & \multicolumn{2}{c}{ Total } \\
& $\mathrm{n}$ & $(\%)$ & $\mathrm{n}$ & $\%$ & $\mathrm{n}$ & $\%$ \\
\hline Elemantary school & 19 & 15.1 & 8 & 6.5 & 27 & 10.8 \\
Junior high school & 34 & 27.0 & 15 & 12.1 & 49 & 19.6 \\
Senior high school & 56 & 44.4 & 60 & 48.4 & 116 & 46.4 \\
University & 17 & 13.5 & 41 & 33.1 & 58 & 23.2 \\
Total & 126 & 100.0 & 124 & 100.0 & 250 & 100.0 \\
\hline
\end{tabular}

\subsubsection{The respondents reason did not use vasectomy}

Table 2 shows respondent reason did not use vasectomy. Based on Table 2, there are three reasons that cause the majority of respondents did not use vasectomy, which still wants to have children $(34 \%)$, reasons related to religion by $18.4 \%$, and $16.8 \%$ are afraid surgery.

Table 2. Reason of Not Use Vasectomy

\begin{tabular}{|c|c|c|c|c|c|c|}
\hline \multirow{2}{*}{ Reason Did Not Use Vasectomy } & \multicolumn{2}{|c|}{ Counseling without Module } & \multicolumn{2}{|c|}{ Counseling by Module } & \multicolumn{2}{|c|}{ Total } \\
\hline & $\mathrm{n}$ & $(\%)$ & $\mathrm{n}$ & $\%$ & $\mathrm{n}$ & $\%$ \\
\hline Want to have children & 42 & 33.3 & 43 & 34.7 & 85 & 34.0 \\
\hline Scared toward surgery & 23 & 18.3 & 19 & 15.3 & 42 & 16.8 \\
\hline Have not a children & 2 & 1.6 & 1 & .8 & 3 & 1.2 \\
\hline Costs & 0 & 0 & 2 & 1.6 & 2 & .8 \\
\hline Afraid toward vasectomy risk & 3 & 2.4 & 0 & 0 & 3 & 1.2 \\
\hline Does not know & 2 & 1.6 & 3 & 2.4 & 5 & 2.0 \\
\hline Not ready & 5 & 4.0 & 2 & 1.6 & 7 & 2.8 \\
\hline Unmanly & 13 & 10.3 & 12 & 9.7 & 25 & 10.0 \\
\hline Religion & 23 & 18.3 & 23 & 18.5 & 46 & 18.4 \\
\hline alternative & 0 & 0 & 7 & 5.6 & 7 & 2.8 \\
\hline Permanent contraception & 2 & 1.6 & 1 & .8 & 3 & 1.2 \\
\hline Family planning is wife concern & 6 & 4.8 & 7 & 5.6 & 13 & 5.2 \\
\hline Can not ejaculate & 3 & 2.4 & 2 & 1.6 & 5 & 2.0 \\
\hline Sterile & 2 & 1.6 & 2 & 1.6 & 4 & 1.6 \\
\hline Total & 126 & 100.0 & 124 & 100.0 & 250 & 100.0 \\
\hline
\end{tabular}

\subsubsection{Differences of knowledge and attitudes with counseling}

Based on Table 3, average knowledge of respondent after counseled is 4.6, while respondents were given a module is 6.9. The average value of the respondents' attitudes that got counseling without is 4.6, while the attitude of respondents who have received the counseling by module average score is 5.3.

Table 3. Differences of Knowledge and Attitudes with Counseling

\begin{tabular}{llllr}
\hline & \multicolumn{1}{c}{ Group } & $\mathrm{n}$ & $\mathrm{Mean}$ & $\mathrm{p}$ \\
\hline \multirow{2}{*}{ Knowledge score } & Counseling with modul & 124 & 6.9032 & 10.741 \\
\multirow{2}{*}{ Attitude score } & Counseling without module & 126 & 4.5794 & 0.000 \\
& Counseling with modul & 124 & 5.2661 & \multirow{2}{*}{3.060} \\
& Counseling without module & 126 & 4.6349 & 0.002 \\
\hline
\end{tabular}

\subsubsection{Results of indepth interviews}

Interviews were conducted in four participants from local government, health authorities, and National Family Planning Board (NFPB). The main question is how attitudes toward vasectomy. Various answers in writing showed on Table 4.

Table 4. Answer of Respondent Indepth Interviews

\begin{tabular}{cl}
\hline Participant & \multicolumn{1}{c}{ Answer } \\
\hline Informan 1 & $\begin{array}{l}\text { Male contraceptives and vasectomies I disagree, because family planning women's } \\
\text { concern, vasectomy is the same in the gelding } \\
\text { Disagree vasectomy because it is not in accordance with the teachings of Islam, Family } \\
\text { Planning quite wife do }\end{array}$ \\
Informan 3 & $\begin{array}{l}\text { Disagree, although i work at NFPB, because vasectomy provide opportunities to } \\
\text { cheating of husband. } \\
\text { This father did not have children, and he is disagree with vasectomy because not } \\
\text { accordance with moslem way of life. }\end{array}$ \\
\hline
\end{tabular}




\subsection{Discussion}

The Vasectomy module is tested to 124 respondents, then measured effectiveness by comparing with respondents who have received counseling without module. The results showed there were differences in the value of knowledge and attitudes, where the average knowledge of respondents who have received the module are higher than respondents who have received counseling. Average knowledge of respondents who got a module is 6.9 , while respondents who received counseling is 4.6 . This difference statistically was significant $(\mathrm{p}=0.000)$. There is no difference in attitude measurement results, respondents who got a counseling by module having a score higher than the attitude of respondents who have received counseling without module. The average score of the attitude of respondents who got a counseling by module is 5.3, while respondents who received counseling without module is 4.6. The attitude score difference statistically was significant (p-0.002).

The results above show the methods of health promotion with the media module is more effective in improving knowledge of the respondent. Selection methods in health promotion should pay attention to the factors that influence the success of health promotion, including the ability of the promoter, the state of the target group [23]. The module is one of the media health promotion in the form of reading material. In substance modules that emphasize the independence (self-learning). Modules can be formulated as a complete unit and stand-alone unit and consists of a series of activities organized help participants achieve a number of objectives that were defined specifically and clearly. Media module spur creativity and provide opportunities for participants to master the material in accordance with the circumstances of each. The module fits perfectly with the state of society in the study because flexibility is used. Counseling module is one of the effective methods to disseminate audiovisual vasectomies. According to Bhandari and Shrestha [24], audiovisual media exposure is important for men in determining the behavior associated with contraception.

Various studies regarding the use of media to promote the active participation of men in family planning programs shows that the media is very important as a means to promote family planning program [25]-[29]. Research conducted by Musafaah [30] showed that the respondents were exposed to the mass media more in the program of family planning than those not exposed to the mass media. There is a significant relationship between the mass media access to the contraceptive method in males [25]. Effectiveness research conducted by media modules have Sutanto, et al [31] which examined the effectiveness of nutrition counseling modules, where the modules are effective in improving posture but is not effective for knowledge and behavior.

Knowledge and Attitudes is a predictor of a person's behavior. The use of modules in health promotion is expected to change the behavior of people to use a vasectomy. The findings of this study describes the various constraints affecting the successful use of vasectomy as a male contraceptive in North Kolaka. Various obstacles can be seen from the results of research on the reasons for refusal vasectomy and from interviews with health authorities, local governments, and employees at NFPB. The results of the study describes the views of men about vasectomy drawn from answering questions reason not to use the largest such vasectomy because they want to have children, fear of surgery, religion (moslem perception), and lost virility. In this study did not find an association between vasectomy disapproval reasons to education. Research conducted by Biestch [27] found that people who are highly educated more receive family planning program.

The results of in-depth interviews ranks of government and related agencies illustrates how a vasectomy rejection associated with ignorance of which is based on the answers that family planning is a woman's problem, as well as vasectomies in the gelding. Another significant reason is related to religion. The results show $46 \%$ of respondents claim to reject family planning because of religion (majority religion of society in North Kolaka is a moslem). It also strengthened the results of in-depth interviews, where some respondents answered vasectomy is contrary to the teachings of the religion (Islam perception). Research conducted by Biestch [27] reported that among muslims is lower in receiving family planning program compared Christians society. Another reason respondents do not approve of vasectomy is their worriers if his wife have perception that vasectomy make husband aesy to cheating.

In contrast to research conducted by Khalifa [32] reported that $91 \%$ of men in sudan receive family planning programs if their wives are in poor health, while $57 \%$ of men in Sudan using family planning programs because of economic limitations. Pakistan reported that more men are receiving contraceptive use than women [33]. The results of in-depth interviews to provide input regarding further intervention which may be made by the NFPB in order to increase the participation of men in family planning programs, especially vasectomies. In line with research conducted by Buzy and Smith [34] reported that the interview with Focus groups can increase the male role in providing input for the success of the intervention program on male contraception. 
The success of vasectomy contraceptive method also requires the support of religion leaders or religion institutios to accelerate the success of vasectomy. Advocacy of religions institutions of Indonesia should be conducted related to family planning program. The module is more effective to improving knowledge and attitudes than counseling without module. The most reason for rejection vasectomy was they want to have children, fear of surgery and religious issues.

\section{CONCLUSION}

The results of this study showed that vasectomy module can be used as an effective method to increase acceptability of male sterilization among men in North Kolaka, Southeast Sulawesi. Besides that, the success of vasectomy module also requires the support of religion leaders in North Kolaka.

\section{ACKNOWLEDGEMENTS}

The authors are gratefull to the instituton Polytechnic of health Kendari, Ministry of Health of Republic Indonesia, for the financial support.

\section{REFERENCES}

[1] Na'im A. and Syaputra H., "Kewarganegaraan, Suku Bangsa, Agama, Dan Bahasa Sehari-Hari Penduduk Indonesia : Hasil Sensus Penduduk 2010," Jakarta, Badan Pusat Statistik, pp. 63, 2011.

[2] Agency for population and family planning, "Draft Grand Strategy to Increase Participation of Men as participant KB," Jakarta, 2006.

[3] Dwijayanti R., "Analysis of responses to the village community, family planning program in order to improve the quality of human resources in the village Cihideung Udik Bogor," 2006.

[4] Brindis C., et al., "Let's hear it for the guys. Int J Mens Health. 2005;4:29-53. Brindis C, MB, Flores-Sanchez, VM, R C. Let's hear it for the guys," Int J Mens Health, vol. 4, pp. 29-53, 2005.

[5] Sonfield A., "Looking at men's sexual and reproductive health needs," 2002.

[6] Kalmuss D. and Tatum C., "Patterns of men's use of sexual and reproductive health services," vol. 39, pp. 74-81, 2007.

[7] Adewuyi A. and Ogunjuyigbe P., "The role of men in amily Planning en axamination of men's knowledge and ettitude to contraceptive use Among the yorubes," African popul Stud., vol/issue: 18(1), pp. 35-49, 2003.

[8] Olawepo R. and Akedare E., "Men's attitudes towards Family Planning in a traditional center. An exaple from Nigeria," J Soc Sci, vol/issue: 13(2), pp. 83-90, 2006.

[9] Ezeh A., et al., "Men's Fertility, Contraceptive use and reproductive preference," Demographic and Health Survey, Comparative studies. Number 18. Maryland, 1996.

[10] A Adewuyi and Ogunjuyible P., "The role of men in family Planning an examination of men's knowledge and attitude to contraceptive use Among the Yorubas," African popul Stud, vol/issue: 18(1), pp. 35-49, 2003.

[11] Bangladesh Demographiv and Health Survey, "Bangladesh demographic and Healt Survey 1999-2000," USA: Bangladesh, Mitra and Associates, Bangladesh and Macro International, 2001.

[12] BKKBN, "Methods of Contraception Lesson elected," Jakarta, 2012.

[13] Y. Q. G., "Study and Current Status of Female Sterilization Vas in China," Int J Reprod Heal Plan., vol. 29, pp. 320-3, 2010.

[14] F. J. J. M., et al., "Coulson A. vasectomy and Health. Results from a lerge cohort study," JAMA, vol. 252, pp. 1023-9, 1984.

[15] C. S. Wang and G. Waites, "Male Contraception: 1993 and beyond," Research a. Van LP, Perez P, editors, Delhi, Oxford University Press, pp. 121-34, 1994.

[16] Magnani R., et al., "Vasectomy in the United States, 1991 and 1995," AM J Pub Heal, vol/issue: 89(92-4), 1999.

[17] Valsangkar S., et al., "Predictors of no-scapel vasectomy acceptance in Karimnagar district, Andhra Pradesh," Indian J Urol., vol. 28, pp. 292-6, 2012.

[18] Sultra B., "Profile southeast Sulawesi BKKBN," Kendari, 2013.

[19] Donta B., et al., "Acceptability of male condom: An Indian scenario," Indian J Med Res., vol. 140, pp. 152-6, 2014.

[20] A. V. Marcell, et al., "National needs of family planning Among US men aged 15 to 44 years," Am J Public Health, vol/issue: 106(4), pp. 733-9, 2016.

[21] Sugiyono, "Non Parametric Statistics for Research," Jakarta, Alfa Beta, 2006.

[22] Lameshow S. and W. H. J. Paud, "Sample size in health research (translation)," Yogyakarta, Gadjah Mada University Press, 1997.

[23] I. W. Mubarak, "Health Promotion for Midwifery," Jakarta, Salemba Medika, 2011.

[24] P. Bhandari and S. Shrestha, "Mass Media, gender, and contraception in Nepal," The Population Research study, 2005.

[25] Mosiur R., et al., "Male contracevtive behavior in Rajshahi District of Bangladesh," Int Med J., vol/issue: 7(2), pp. $15-20,2008$ 
[26] Winarni E. and Dawam M., "Family Planning Information, Education and Communication with Contaceptive Use," Public Health Public Heal J Natl, vol/issue: 11(2), pp. 94-102, 2016.

[27] Bietsch K. and K. E. Bietsch, "Men's Attitudes T owards Contraception in Sub-Saharan Africa," vol. 19, pp. 41-54, 2015.

[28] Oni G. and McCarthy J., "Family Planning Knowledge, Attitudes and Practice of Males in Florin, Nigeria," International Family Planning Perspectives, vol/issue: 17(2), pp. 50-64, 1991.

[29] Stenberg P. and Hubley J., "Evaluating Men's Involvement as a strategy in Sexual and reproductive Health Promotion," Health Promot Int., vol/issue: 19(3), pp. 389-96, 2004.

[30] M. Musafaah M., "Participation in Family Planning Program in Indonesia," J Public Health Kesehat society should Nas., vol/issue: 7(4), pp. 158-61, 2012.

[31] Sutanto, et al., "Intensive Nutrition Counseling Training Module, for Pregnant and Breastfeeding," Indones Med Assoc., vol/issue: 63(2), 2012.

[32] Khalifa M. A., "Attitudes toward Men of Urban Sudanese Family Planning," vol/issue: 19(4), pp. 236-43, 1988.

[33] Mahmood N. and Ringheim K., "Factors affecting contraceptive use in Pakistan," Mr. Dev Rev., vol/issue: 35(1), pp. 1-22, 1996.

[34] Buzi R. S. and Smith P. B., "Access to Sexual and Reproductive Health Care Services: Young Men's Perspectives," J Sex Marital Ther, vol/issue: 40(2), pp. 149-57, 2014. 